\title{
Pengaruh Permintaan dan Penawaran Terhadap Profitabilitas Karena \\ Adanya Pembatasan Perilaku Masyarakat Pada \\ PT Lotte Chemical Titan Tbk. Di Makassar
}

\author{
AYAT ARIFANDY ADRIE, (DR. ROSNAINI DAGA, S.E., M.M.) \\ INSTITUT BISNIS DAN KEUANGAN NITRO
}

ayatarifandy@gmail.com

\begin{abstract}
ABSTRAK
Judul penelitian ini adalah "Pengaruh Permintaan dan Penawaran Terhadap Profitabilitas Karena Adanya Pembatasan Perilaku Masyarakat Pada PT Lotte Chemical Titan Tbk. Di Makassar" penelitian ini bertujuan untuk mengetahui pengaruh permintaan dan penawaran terhadap profitabilitas PT Lotte Indonesia di Makassar karena adanya Pembatasan Perilaku Masyarakat. Dimana, diharapkan dapat tetap menyediakan dan memperhatikan kebutuhan masyarakat, agar tidak terjadi tingkat penurunan permintaan atau pertambahan penawaran. Jenis penelitian ini adalah penelitian kuantitatif yaitu data mengenai laporan keuangan perusahaan PT Lotte Chemical Titan Tbk periode tahun 2019-2020. Kemudian data diperoleh dari dokumen yaitu penelitian dengan mengumpulkan data laporan keuangan PT Lotte Chemical Titan Tbk melalui website resmi dan merupakan data sekunder.
\end{abstract}

\section{PENDAHULUAN}

\section{A. LATAR BELAKANG}

Saat ini LOTTE tumbuh menjadi produsen permen nomor satu dengan sebutan "The Sweetheart of Your Mouth" melalui berbagai produk yang kami 
tawarkan termasuk permen karet, coklat dan kue. Kami sangat berterima kasih atas dukungan Anda hingga saat ini.

LOTTE kini berkembang menjadi perusahaan global yang mempunyai lebih dari 50 anak perusahaan di Jepang dan luar negeri. Terbatasnya tempat untuk memperkenalkan dan berbagi informasi tentang bisnis dan produk kami, jadi kami sangat senang jika website ini bisa membantu anda mengenal dan memahami LOTTE.

Permintaan dan penawaran merupakan dua aktivitas yang mendasari kegiatan perekonomian. Permintaan dan penawaran juga merupakan dua kata yang paling sering digunakan oleh para ekonom, keduanya merupakan kekuatankekuatan yang membuat perekonomian pasar bekerja. Sedangkan mekanisme pasar itu sendiri adalah interaksi yang terjadi antara permintaan (demand) dari sisi konsumen dan penawaran

Harga keseimbangan adalah harga dimana baik konsumen maupun produsen sama-sama tidak ingin menambah atau mengurangi jumlah yang dikonsumsi atau dijual. Permintaan sama dengan penawaran. Jika harga dibawah harga keseimbangan, terjadi kelebihan permintaan. Sebab permintaan akan meningkat, dan penawaran menjadi berkurang. Sebaliknya jika harga melebihi harga keseimbangan, terjadi kelebihan penawaran. Jumlah penawaran meningkat, jumlah permintaan menurun.

Berdasarkan uraian diatas, maka dengan ini penulis tertarik untuk melakukan penelitian dengan mengangkat judul "Pengaruh Permintaan dan Penawaran Terhadap Profitabilitas Karena Adanya Pembatasan Perilaku Masyarakat Pada PT Chemical Titan Tbk Di Makassar". 


\section{B. RUMUSAN MASALAH}

Berdasarkan latar belakang yang telah dikemukakan di atas, maka yang menjadi rumusan masalah dalam penelitian ini yaitu:

1. Apakah Permintaan berpengaruh terhadap Profitabilitas PT Lotte Indonesia Di Makassar karena adanya Pembatasan Perilaku Masyarakat?

2. Apakah Penawaran berpengaruh terhadap Profitabilitas PT Lotte Indonesia Di Makassar karena adanya Pembatasan Perilaku Masyarakat?

\section{TUJUAN PENELITIAN}

Berdasarkan rumusan masalah di atas, maka yang menjadi tujuan dalam penelitian ini yaitu:

a. Untuk mengetahui pengaruh Permintaan terhadap Profitabilitas PT Lotte Indonesia Di Makassar karena adanya Pembatasan Perilaku Masyarakat.

b. Untuk mengetahui pengaruh Permintaan terhadap Profitabilitas PT Lotte Indonesia Di Makassar karena adanya Pembatasan Perilaku Masyarakat.

\section{TINJAUAN PUSTAKA}

\section{A. LANDASAN TEORI}

\section{Definisi Profitabilitas}

a. Profitabilitas

Profitabilitas adalah kemampuan perusahaan untuk mendapatkan laba (profit). Rasio profitabilitas dapat digunakan sebagai indikator keberhasilan usaha (Azwar dan Karuniyati, 2008). 
b. Jenis Jenis Rasio Profitabilitas

\section{a. Margin Laba Kotor (Gross Profit Margin)}

Margin laba kotor merupakan rasio profitabilitas untuk menilai persentase laba kotor terhadap pendapatan yang dihasilkan dari penjualan. Laba kotor yang dipengaruhi oleh laporan arus kas memaparkan besaran laba yang didapatkan oleh perusahaan dengan pertimbangan biaya yang terpakai untuk memproduksi produk atau jasa.

\section{b. Margin Laba Bersih (Net Profit Margin)}

Net profit margin atau margin laba bersih merupakan rasio profitabilitas untuk menilai persentase laba bersih yang didapat setelah dikurangi pajak terhadap pendapatan yang diperoleh dari penjualan. Margin laba bersih ini disebut juga profit margin ratio. Rasio ini mengukur laba bersih setelah pajak terhadap penjualan. Semakin tinggi Net profit margin semakin baik operasi suatu perusahaan.

c. Rasio Pengembalian Aset (Return on Assets Ratio)

Tingkat pengembalian aset merupakan rasio profitabilitas untuk menilai persentase keuntungan (laba) yang diperoleh perusahaan terkait sumber daya atau total asset sehingga efisiensi suatu perusahaan dalam mengelola asetnya bisa terlihat dari persentase rasio ini.

d. Return on Equity Ratio (Rasio Pengembalian Ekuitas)

Return on Equity Ratio (ROE) merupakan rasio profitabilitas untuk menilai kemampuan perusahaan dalam menghasilkan laba dari 
investasi pemegang saham perusahaan tersebut yang dinyatakan dalam persentase. ROE dihitung dari penghasilan (income) perusahaan terhadap modal yang diinvestasikan oleh para pemilik perusahaan (pemegang saham biasa dan pemegang saham preferen). Return on equity menunjukkan seberapa berhasil perusahaan mengelola modalnya (net worth), sehingga tingkat keuntungan diukur dari investasi pemilik modal atau pemegang saham perusahaan.

\section{e. Return on Sales Ratio (Rasio Pengembalian Penjualan)}

Return on Sales merupakan rasio profitabilitas yang menampilkan tingkat keuntungan perusahaan setelah pembayaran biaya-biaya variabel produksi seperti upah pekerja, bahan baku, dan lain-lain sebelum dikurangi pajak dan bunga. Rasio ini menunjukkan tingkat keuntungan yang diperoleh dari setiap rupiah penjualan yang juga disebut margin operasional (operating margin) atau Margin pendapatan operasional (operating income margin).

f. Return on Capital Employed (Pengembalian Modal yang digunakan)

Return on Capital Employed (ROCE) merupakan rasio profitabilitas yang mengukur keuntungan perusahaan dari modal yang dipakai dalam bentuk persentase (\%). Modal yang dimaksud adalah rkuitas suatu perusahaan ditambah kewajiban tidak lancar atau total aset dikurangi kewajiban lancar. ROCE mencerminkan efisiensi dan profitabilitas modal atau investasi perusahaan.

g. Return on Investment (ROI) 
Return on investment merupakan rasio profitabilitas yang dihitung dari laba bersih setelah dikurangi pajak terhadap total aktiva. Return on investment berguna untuk mengukur kemampuan perusahaan secara keseluruhan dalam menghasilkan keuntungan terhadap jumlah aktiva secara keseluruhan yang tersedia pada perusahaan. Semakin tinggi rasio ini berarti semakin baik kondisi suatu perusahaan.

h. Earning Per Share (EPS)

Earning per share merupakan rasio profitabilitas yang menilai tingkat kemampuan per lembar saham dalam menghasilkan laba untuk perusahaan. Manajemen perusahaan, pemegang saham biasa dan calon pemegang saham sangat memperhatikan earning per share karena menjadi indikator keberhasilan perusahaan.

c. Faktor yang memepengaruhi profitabilitas

Rasio profitabilitas yang penting untuk dijadikan penilaian terhadap tingkat kesehatan perusahaan yaitu Return on Equity (ROE) yang menggambarkan kemampuan menghasilkan laba dari setiap rupiah modal ekuitasnya dan merupakan saham yang dimiliki investor (publik) atau dengan kata lain ROE menunjukkan tingkat efisiensi dari investasi modal yang diperoleh dari investor (Sartono, 2008).

\section{Definisi Permintaan}

a. Permintaan

Permintaan adalah keinginan yang disertai dengan kesediaan serta kemampuan untuk membeli barang yang bersangkutan. Setiap orang boleh saja ingin kepada apapun yang diinginkannya, tetapi jika 
keinginannya ini tidak ditunjang dengan kesediaan membeli serta kemampuannya untuk membeli, maka keinginannya itu pun hanya akan tinggal keinginan saja.

Oleh karena itu, keinginan tidak berpengaruh terhadap harga. Dan permintaan memiliki pengertian yang lebih dalam daripada keinginan. Permintaan akan sesuatu jenis barang ialah jumlah jumlah barang itu yang pembeli bersedia membelinya pada tingkat harga yang berlaku pada suatu pasar tertentu pula.

b. Faktor-faktor yang mempengaruhi perminntaan

a. Harga barang itu sendiri

Harga barang/jasa itu sendiri berpengaruh terhadap yang diminta

b. Pendapatan masyarakat

Pada barang normal, peningkatan pendapatan akan meningkatkan jumlah barang/jasa yang diminta. Namun pada barang inferior (nasi dan jagung), peningkatan pendapatan justru akan mengurangi jumlah barang/jasa yang diminta.

c. Intensitas kebutuhan

Semakin penting barang/jasa dalam memenuhi kebutuhan seseorang maka jumlah permintaannya akan semakin meningkat. Misalnya permintaan masker karena adanya kasus penyebaran virus.

d. Jumlah penduduk

Semakin besar jumlah penduduk di suatu ngara maka semakin besar permintaannya terhadap barang/jasa.

e. Selera 
Peningkatan selera pada satu jenis barang/jasa akan meningkatkan permintaan terhadap barang/jasa tersebut dibandingkan dengan jenis barang/jasa lainnya.

f. Barang pengganti

Ketersediaan barang pengganti berpengaruh terhadap jumlah barang dan jasa yang diminta. Ketika harga the meningkat, masyarakat yang menganggap kopiadalah barang subtitusi dari the akan mengalihkan pembeliannya ke kopi sehingga permintaan kopi akan meningkat.

c. Fungsi Permintaan

Fungsi permintaan adalah kajian matematis yang dipakai dalam menganalisis perilaku konsumen dan keterkaitannya dengan harga produk. Pada fungsi permintaan, harga barang berbanding terbalik dengan jumlah permintaan.

Permintaan atas permintaan dari pembeli akan meningkat. Jadi, hubungan antara harga dan jumlah barang yang dibeli oleh pelanggan memiliki hubungan yang terbalik, sehingga gradien dari fungsi permintaan (b) akan selalu negatif.

\section{Definisi Penawaran}

a. Penawaran

Penawaran adalah keseluruhan jumlah barang yang tersedia untuk ditawarkan pada berbagai tingkat harga tertentu dan waktu tertentu. Jika harga naik, jumlah barang yang ditawarkan bertambah. Begitu juga ketika harga turun, maka jumlah barang yang ditawarkan juga turun atau semakin sedikit. 
Peran penawaran sangat penting dalam dunia ekonomi, karena dapat digunakan sebagai analisa ekonomi mikro. Penawaran juga dapat digunakan sebagai titik tolak bagi berbagai model dan teori ilmu ekonomi lainnya. Dari penawaran akan dapat digunakan sebagai perkiraan harga yang berfungsi sebagai penyeimbang antara kuantitas yang diminta dan kuantitas yang ditawarkan dalam pasar yang kompetitif.

b. Faktor-faktor yang Mempengaruhi Penawaran

\section{a. Harga Barang}

Harga barang menjadi faktor utama besar kecilnya penawaran. Semakin tinggi harga barang, maka semakin tinggi pula penawaran yang dilakukan oleh konsumen.

b. Jumlah Penjual atau Produsen

Jika jumlah produsen suatu barang tertentu tinggi, maka jumlah penawaran terhadap barang tersebut juga akan tetap tinggi. Misalnya, jika suatu daerah menjadi sentra penghasil sepatu. Maka penawaran sepatu di daerah tersebut akan tinggi.

\section{c. Bencana Alam}

Jika terjadi bencana alam pada suatu daerah penghasil suatu produk. Maka bisa dipastikan bahwa jumlah produksi barang tersebut akan menurun dan mempengaruhi tingkat penawarannya.

d. Harga Barang Pengganti

Apabila harga suatu barang meningkat maka penawaran terhadap barang pengganti akan mengalami peningkatan karena penjual akan menawarkan barang pengganti sebagai alternatif barang utama yang mengalami kenaikan. Contohnya harga kopi meningkat 
menyebabkan harga barang penggantinya yaitu teh terlihat lebih rendah, sehingga penjual lebih banyak menjual teh.

e. Biaya Produksi

Biaya produksi berkaitan dengan biaya yang digunakan dalam proses produksi, seperti biaya untuk membeli bahan baku, biaya untuk gaji pegawai, biaya untuk bahan-bahan penolong, dan sebagainya. Apabila biaya-biaya produksi meningkat, maka harga barang barang diproduksi akan tinggi. Akibatnya produsen akan menawarkan barang produksinya dalam jumlah yang sedikit.

\section{f. Kemajuan Teknologi}

Kemajuan teknologi sangat berpengaruh terhadap besar kecilnya barang yang ditawarkan. Adanya teknologi yang lebih modern akan memudahkan produsen dalam menghasilkan barang dan jasa. Selain itu dengan menggunakan mesin-mesin modern akan menurunkan biaya produksi dan akan memudahkan produsen untuk menjual barang dengan jumlah yang banyak. Dalam hubungannya dengan penawaran suatu barang, kemajuan teknologi menimbulkan dua efek, yaitu produksi dapat ditambah dengan lebih cepat dan biaya produksi semakin murah sehingga keuntungan bertambah tinggi.

\section{g. Pajak}

Pajak yang merupakan ketetapan pemerintah terhadap suatu produk sangat berpengaruh terhadap tinggi rendahnya harga. Jika pajak suatu barang menjadi tinggi, maka permintaan akan berkurang, sehingga penawaran juga akan berkurang.

h. Perkiraan Harga di Masa Depan 
Perkiraan harga di masa datang sangat memengaruhi besar kecilnya jumlah penawaran. Jika perusahaan memperkirakan harga barang dan jasa naik, sedangkan penghasilan masyarakat tetap, maka perusahaan akan menurunkan jumlah barang dan jasa yang ditawarkan. Misalnya pada saat krisis ekonomi, harga-harga barang dan jasa naik, sementara penghasilan relatif tetap. Akibatnya perusahaan akan mengurangi jumlah produksi barang dan jasa, karena takut tidak laku.

i. Kebijakan Pemerintah dan Situasi Politik

Kebijakan pemerintah juga memengaruhi komoditas pasar. Misalnya kebijakan kenaikan bea cukai atau penghapusan bea cukai. Selain kebijakan pemerintah, situasi politik dalam suatu negara juga memengaruhi penawaran. Jika suatu negara dalam situasi politik yang kritis, maka semakin tinggi penawaran pasar.

\section{c. Fungsi Penawaran}

fungsi yang menunjukkan hubungan antara harga barang atau jasa yang dipasar dengan penawaran harga yang ditawarkan oleh seorang produsen. Fungsi penawaran digunakan oleh produsen dengan tujuan untuk menganalisa pembahasan yang akan diterbitkan.

Dengan mempertimbangkan faktor harga yang ditawarkan naik, dengan asumsi cateris paribus (faktor-faktor lain dianggap tetap), maka jumlah barang yang ditawarkan akan naik, dan sebaliknya meningkatkan harga barang meningkat jumlah barang yang ditawarkan juga meningkat. Jadi, dalam fungsi penawaran antara harga barang dan jumlah 
barang yang ditawarkan oleh produsen memiliki hubungan positif, gradien

(b) dari fungsi penawaran selalu positif.

\section{Hubungan antara Permintaan dan Profitabilitas}

Tingkat pertumbuhan penjualan dapat juga mempengaruhi profitabilitas perusahaan. Semakin tingginya penjualan bersih yang dilakukan oleh perusahaan dapat mendorong semakin tingginya laba kotor yang mampu diperoleh, sehingga dapat mendorong semakin tingginya profitabilitas perusahaan. Hal ini sejalan dengan ukuran dari sebuah perusahaan. Dengan semakin besarnya ukuran perusahaan, maka akan mencerminkan semakin besarnya sumber daya yang tersedia untuk memenuhi permintaan produk. Di samping itu, dengan semakin besarnya ukuran dari sebuah perusahaan, maka perusahaan memiliki kesempatan untuk menjangkau pangsa pasar yang lebih luas untuk melakukan pemasaran produknya, sehingga membuka peluang diperolehnya laba yang semakin tinggi.

\section{Hubungan antara Penawaran dan Profitabilitas}

Setidaknya guncangan ekonomi yang terjadi akibat pembatasan perilaku memengaruhi sisi penawaran (supply side shock). Dari sisi penawaran, penyebaran COVID-19 jelas akan memberikan dampak pada kesehatan tenaga kerja dan akan secara langsung menurunkan tingkat produktivitas tenaga kerja. Selain itu dalam rangka mencegah penularan virus yang semakin luas dengan melakukan pembatasan mobilitas, secara ekonomi hal tersebut akan membuat produktivitas menurun. Baldwin dan Di Mauro menjelaskan bahwa penurunan produktivitas tersebut mirip dengan penurunan sementara 
dalam jumlah tenaga kerja. Sedangkan dari sisi permintaan, COVID-19 memiliki pengaruh terhadap permintaan agregat melalui dua aspek, yaitu aspek praktis dan psikologis. Pada aspek praktis, COVID-19 membuat pergerakan konsumen semakin jarang untuk keluar rumah, sehingga frekuensi transaksi akan relatif lebih rendah dan tingkat konsumsi menjadi menurun. Sedangkan dari aspek psikologis, COVID-19 membuat agen ekonomi menghadapi ketidakpastian, sehingga konsumen dan perusahaan akan cenderung melakukan "wait and see" dalam keputusan ekonominya, atau dengan kata lain menahan kegiatan konsumsi dan investasinya. Hal tersebut akan membuat permintaan secara agregat akan menurun.

\section{B. Hipotesis Penelitian}

Berdasarkan landasan teori dan penelitian terdahulu yang telah dikemukakan, maka hipotesis dalam penelitian ini :

$\mathrm{H} 1$ : $\quad$ Permintaan berpengaruh positif terhadap profitabilitas pava perusahaan PT Lotte Indonesia di Makassar.

H2 : $\quad$ Penawaran berpengaruh positif terhadap profitabilitas pava perusahaan PT Lotte Indonesia di Makassar.

\section{Kerangka Berfikir}

\section{Gambar}

\section{Kerangka Berfikir}

\section{PERUSAHAAN PT LOTTE INDONESIA}

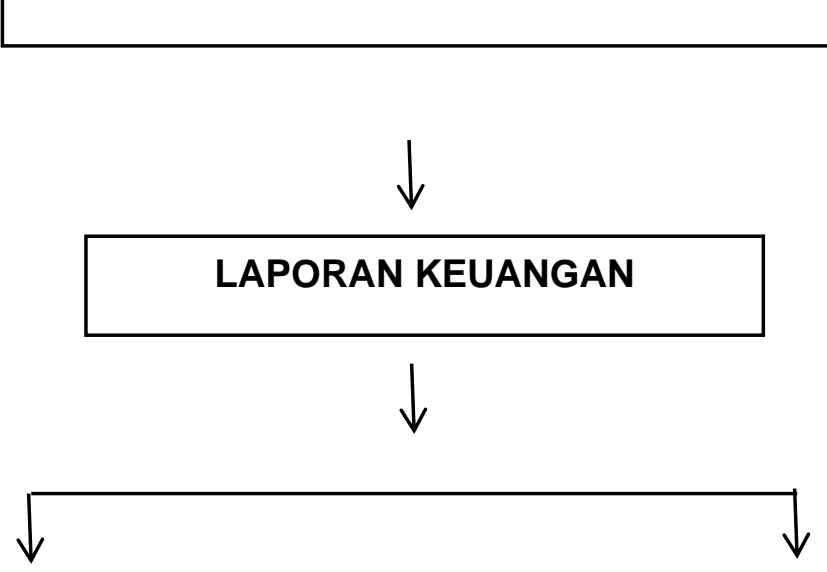




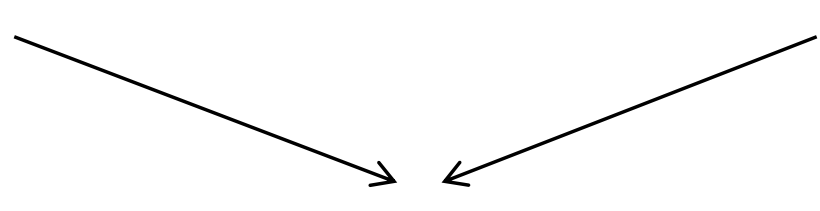

\section{PROFITABILITAS}

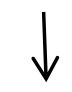

\section{KESIMPULAN dan SARAN}

Keterangan :

Penelitian ini dilakukan di PT Lotte Indonesia, dengan memperhatikan manajemen keuangan perusahaan bagian profitabilitas sebagai data penelitian. Variabel indepen yang digunakan adalah permintaan dan penawaran, untuk melihat pengaruh keua variable tersebut secara parsial terhadap Profitabilitas. Sehingga dapat diratik kesimpulan dan saran sebagai bahan masukan perusahaan PT Lotte Indonesia di Makassar.

\section{METODE PENELITIAN}

\section{A. LOKASI DAN WAKTU PENELITIAN}

Penelitian ini dilakukan di PT Lotte Chemical Titan Tbk yang berlokasi di Jl. Sulltan Alauddin No. 87, Kota Makassar. Dan waktu penelitian selama kurang lebih satu bulan.

\section{B. JENIS DAN SUMBER DATA}




\section{Jenis Data}

Jenis data yang digunakan dalam penelitian ini adalah berupa data kuantitatif, yaitu data mengenai laporan keuangan perusahaan PT Lotte Chemical Titan Tbk periode tahun 2019-2020.

\section{Sumber Data}

Sumber data yang digunakan dalam penelitian ini adalah data sekunder. Data ini diperoleh dalam bentuk data yang telah dikumpulkan, diolah, didokumentasikan dan dipubliskan oleh perusahaan PT Lotte Chemical Titan Tbk berupa data laporan keuangan periode 2019-2020.

\section{TEKNIK PENGUMPULAN DATA}

Adapun teknik pengumpulan data yang digunakan adalah Studi Dokumen yang dimana pengumpulan data-data yang diambil dari dokumen yaitu penelitian dengan mengumpulkan data laporan keuangan PT Lotte Chemical Titan Tbk melalui website resmi dan merupakan data sekunder.

\section{POPULASI DAN SAMPEL}

\section{Populasi}

Populasi dalam penelitian ini adalah seluruh laporan keuangan PT Lotte Chemical Titan Tbk

\section{Sampel}

Sampel dalam penelitian ini adalah laporan keuangan PT Lotte Chemical Titan Tbk Periode tahun 2019-2020

\section{E. ANALISIS DATA}


Metode analisis data yang digunakan dalam penelitian ini adalah deskritif kuantitatif dengan bantuan Rasio Keuangan Aspek Profitabilitas PT Lotte Chemical Titan Tbk

1. Aspek profitabilitas adalah aspek yang mengukur PT Lotte Chemical Titan Tbk untuk memperoleh laba. Aspek profitabilitas diukur dengan rasio profitabilitas, yakni rasio yang mengukur kemampuan perusahaan dalam menghasilkan tingkat laba atas penggunaan aset dan ekuitas PT Lotte Chemical Titan Tbk. Adapun rasio profitabilitas yang digunakan, antara lain :

a. Gross Profit Margin

Gross Profit Margin yaitu rasio yang digunakan untuk mengukur besarnya persentasi laba kotor atas penjualan bersih. Gross Profit Margin $=\frac{\text { Laba Kotor }}{\text { Penjualan Bersih }} \times 100 \%$

b. Operating Profit Margin

Operating Profit Margin yaitu rasio yang digunakan untuk mengukur kemampuan perusahaan dalam menghasilkan laba operasi (laba usaha) dari penjualan bersih perusahaan selama periode waktu tertentu.

Operating Profit Margin $=\frac{\text { EBIT }}{\text { Penjualan Bersih }} \times 100 \% 35$

c. Net Profit Margin

Net Profit Margin yaitu rasio yang mengukur seberapa besar laba bersih yang dihasilkan suatu perusahaan dibandingkan dengan penjualan bersihnya.

Net Profit Margin $=\frac{\text { Net Income }}{\text { Penjualan Bersih }} \times 100 \%$

d. Return on Asset 
Return on Asset yaitu rasio yang mengukur seberapa efektif aset yang ada mampu menghasilkan keuntungan. Return on Assets $=$ $\frac{\text { Net Income }}{\text { Total Assets }} \times 100 \%$

e. Return on Equity

Return on Equity yaitu rasio yang mengukur seberapa besar keuntungan bersih atau keuntungan yang dihasilkan oleh modal sendiri.

Return on Equity $=\frac{\text { Net Income }}{\text { Total Equity }} \times 100 \%$

\section{F. ANALISIS DATA}

Metode analisis data yang digunakan dalam penelitian ini adalah deskritif kuantitatif dengan bantuan Rasio Keuangan Aspek Profitabilitas PT Lotte Chemical Titan Tbk

2. Aspek profitabilitas adalah aspek yang mengukur PT Lotte Chemical Titan Tbk untuk memperoleh laba. Aspek profitabilitas diukur dengan rasio profitabilitas, yakni rasio yang mengukur kemampuan perusahaan dalam menghasilkan tingkat laba atas penggunaan aset dan ekuitas PT Lotte Chemical Titan Tbk. Adapun rasio profitabilitas yang digunakan, antara lain :

f. Gross Profit Margin

Gross Profit Margin yaitu rasio yang digunakan untuk mengukur besarnya persentasi laba kotor atas penjualan bersih. Gross Profit Margin $=\frac{\text { Laba Kotor }}{\text { Penjualan Bersih }} \times 100 \%$

g. Operating Profit Margin

Operating Profit Margin yaitu rasio yang digunakan untuk mengukur kemampuan perusahaan dalam menghasilkan laba operasi (laba 
usaha) dari penjualan bersih perusahaan selama periode waktu tertentu.

Operating Profit Margin $=\frac{\text { EBIT }}{\text { Penjualan Bersih }} \times 100 \% 35$

h. Net Profit Margin

Net Profit Margin yaitu rasio yang mengukur seberapa besar laba bersih yang dihasilkan suatu perusahaan dibandingkan dengan penjualan bersihnya.

Net Profit Margin $=\frac{\text { Net Income }}{\text { Penjualan Bersih }} \times 100 \%$

i. Return on Asset

Return on Asset yaitu rasio yang mengukur seberapa efektif aset yang ada mampu menghasilkan keuntungan. Return on Assets = $\frac{\text { Net Income }}{\text { Total Assets }} \times 100 \%$

j. Return on Equity

Return on Equity yaitu rasio yang mengukur seberapa besar keuntungan bersih atau keuntungan yang dihasilkan oleh modal sendiri.

Return on Equity $=\frac{\text { Net Income }}{\text { Total Equity }} \times 100 \%$

\section{KESIMPULAN}

Hukum permintaan "semakin turun tingkat harga, maka semakin banyak jumlah barang yang diminta, dan sebaliknya semakin naik harga semakin sedikit jumlah barang yang diminta" sedangkan hukum penawaran "semakin tinggi harga, semakin banyak jumlah barang yang ditawarkan, sebaliknya semakin rendah tingkat harga semakin sedikit jumlah barang yang tersedia ditawarkan". Faktor-faktor yang mempengaruhi tingkat permintaan dan penawaran salah satunya adalah gaya hidup. 
Ditengah pandemic Covid-19, agen ekonomi menghadapi ketidakpastian sehingga hal tersebut akan membuat permintaan dan penawaran juga terkena dampaknya atau secara agregat akan menurun.

\section{DAFTAR PUSTAKA}

https://www.studiobelajar.com/permintaan-dan-penawaran/

https://www.kelaspintar.id/blog/tips-pintar/mengenal-konsep-permintaan-penawarandan-harga-pasar-4022/

https://www.linovhr.com/permintaan-dan-penawaran/

https://dosenakuntansi.com/rasio-profitabilitas

https://www.idx.co.id/perusahaan-tercatat/profil-perusahaan-tercatat/detail-profile-

perusahaan-tercatat/?kodeEmiten=FPNI 